\title{
TEP1 wt Allele
}

National Cancer Institute

\section{Source}

National Cancer Institute. TEP1 wt Allele. NCI Thesaurus. Code C52489.

Human TEP1 wild-type allele is located in the vicinity of $14 q 11.2$ and is approximately 46

$\mathrm{kb}$ in length. This allele, which encodes telomerase protein component 1 , is involved in the modulation of the duplication of chromosome termini. 